\title{
Proje Tabanlı Öğretimin Öğrencilerin Öğrenme Tutumları ve Öğretme- Öğrenme Ortamı Algılarına Etkisi
}

\author{
The Impact of Project-Based Teaching on Attitudes Toward Learning and Teaching- \\ Learning Environment Perceptions of Students
}

\author{
Yıldız DENAT ${ }^{1 \text { A,B,C,D,E,F,G }} \mathbb{C}^{\circ}$, Emel TUĞRUL $^{1 \text { C,D,E,F }}$ \\ ${ }^{1}$ Aydın Adnan Menderes Üniversitesi Hemşirelik Fakültesi Hemşirelik Esasları Anabilim Dalı, Aydın, Türkiye
}

ÖZ

\begin{abstract}
Amaç: Araştırma proje tabanlı öğretim yönteminin öğrencilerin öğretme- öğrenme tutumları ve öğretim ortamı algilarına etkisini incelemek amacıyla tek grup ön test- son test yarı deneysel desen olarak planlanmıştır.

Yöntem: Araştırmanın örneklemini Türkiye'nin batısındaki bir üniversitenin hemşirelik fakültesinde 2019-2020 eğitim öğretim yllında hemşirelikte öğretim dersi alan ve çalışmaya katılmayı kabul eden 133 öğrenci oluşturdu. Veriler "Bilgi Formu", "Öğrenmeye İlişkin Tutum Ölçeğı”, "Öğretme-Öğrenme Ortamı Algısı Ölçeği” ile toplandı. Verilerin değerlendirilmesinde frekans, yüzde, aritmetik ortalama, t-testi (Paried Samples t-test) analizleri kullanıldı.

Bulgular: Öğrencilerin öğrenmeye ilişkin tutum ölç̧ği alt faktör puan ortalamaları incelendiğinde öğrencilerin tüm alt faktör puan ortalamalarının proje tabanlı öğretim öncesi ve sonrası oldukça yüksek olduğu öğrenmenin doğasına ilişkin puan ortalamalarının proje tabanlı öğretim sonrası anlamlı düzeyde azaldı̆̆ ( $<<0.05)$, diğer alt faktörler açısından anlamlı bir fark olmadığı ( $>0.05$ ) saptandı. Öğrencilerin öğrenme-öğretme ortamı algısı ölçeği alt faktör puan ortalamaları incelendiğinde öğrencilerin proje tabanlı öğretim sonrası öğretme-öğrenme etkinliklerine ilişkin algılarının anlamlı düzeyde arttığı $(p<0.05)$, değerlendirme ve iş yükü algılarının ise anlamlı düzeyde azaldığı $(p<0.05)$ belirlendi.

Sonuç: Bu çalışma sonucunda proje tabanlı öğretimin öğrencilerin öğrenmenin doğasına ilişkin tutumlarını değiştirdiği, öğrenme-öğrenme ortamının derinlemesine öğrenmeye yönlendiriciliğini arttırdığı saptandı.
\end{abstract}

Anahtar Kelimeler: Proje Tabanlı Öğrenme, Öğrenme Tutumu, Öğrenme Ortamı Algısı, Hemşirelik, Hemşirelik Eğitimi.

\section{ABSTRACT}

Objective: The study was planned in a single-group pretest-posttest quasi-experimental design to examine the impact of projectbased teaching method on attitudes toward learning, and teaching-learning environment perceptions of students.

Methods: Sample of the study consisted of 133 students who receive the lesson of teaching in nursing in a nursing faculty of a university in the west of Turkey during the 2019-2020 academic year and agreed to participate in the study. The data were collected via the "Information Form", "The Scale of Attitudes Toward Learning", "Teaching-Learning Environment Perception Inventory" and were evaluated using frequency, percentage, arithmetic mean and t-test (Paired Samples t-test) analyses.

Results: Examining students' sub-factor score averages of the cale of attitudes toward learning; it was determined that their sub-factor score averages were all very high before and after the project-based teaching, while their score averages related to the nature of learning significantly decreased after the project-based teaching $(\mathrm{p}<0.05)$ and there was no significant difference in terms of other sub-factors ( $>0.05$ ). Examining students' sub-factor score averages of the Teaching-Learning Environment Perception Scale; it was determined that their perceptions regarding teaching-learning activities significantly increased after the project-based teaching $(\mathrm{p}<0.05)$, whereas their assessment and work load perceptions significantly decreased $(\mathrm{p}<0.05)$. Conclusion: As a result of this study, it was determined that project-based teaching changed students' attitudes toward the nature of learning and increased their tendency to learn the teaching-learning environment profoundly.

Key words: Project-Based Learning, Learning Attitude, Learning Environment Perception, Nursing, Nursing Education.

Sorumlu Yazar: Yildız DENAT

Aydın Adnan Menderes Üniversitesi Hemşirelik Fakültesi Hemşirelik Esasları Anabilim Dalı, Aydın, Türkiye

denat09@gmail.com

Geliș Tarihi: 03.03.2020 - Kabul Tarihi: 26.05.2020

Yazar Katkıları: A) Fikir/Kavram, B) Tasarım, C) Veri Toplama ve/veya İşleme, D) Analiz ve/veya Yorum, E) Literatür

Taraması. F) Makale Yazımı. G) Elestirel İnceleme 


\section{GíRiş}

Günümüzde dünya hızla gelişmekte, belirli bir alanda yetiştirilen bir bireyin mezuniyetinde almış olduğu eğitim gelişmelerden dolayı neredeyse tamamen değişmektedir. Bilginin bu kadar hızlı değiştiği bir toplumda bireylerin gelişimi ve değişimi yakalamaları için öncelikle öğrenmeye yönelik olumlu tutumlar geliştirmiş ve öğrenmeye karşı kayg1 durumundan uzaklaşmış olmaları gerekmektedir. Nitekim bireylerin öğrenmeye yönelik yaklaşımları öğrenme sonuçlarını etkilemektedir. Yapılan çalışmalarda bireylerin öğrenmeye yönelik olumlu tutumlara sahip olduklarında öğrenmede daha iyi bir durum sergiledikleri belirlenmiştir (1-3). Braten ve Stromson'ın (2006) yaptığ çalışmada, öğrencilerin bir konuyu öğrenmeye yönelik tutumlarının, öğrenmek için gerekli aktivitelere katılma durumlarını yönlendirdiği, bilgi edinmeye yönelik inançlarının da bilgi edinme performanslarını önemli ölçüde etkilediği saptanmıştır (1). Yapılan çalışma sonuçlarına göre konu veya derse yönelik olumlu tutumlar derse veya konuya yönelik öğrenci motivasyonlarını artırmakta, akademik başarılarıda olumlu yönde etkilemektedir (1-4).

Eğitim sürecinde öğrencilere öğrenmeye ilişkin olumlu tutumların kazandırılması kadar önemli bir diğer konu da öğretme- öğrenme ortamına ilişkin algılardır. Çünkü öğrenmeye ilişkin olumlu tutumların gelişmesinde öğrenme ortamı da etkin bir rol oynamaktadır $(5,6)$. Karagiannopoulou ve Christtodoulides (2005) araştırmalarında üniversite giriş sınavlarından ziyade, öğrencinin öğrenme ortamına yönelik tutumlarının akademik başarıda etkili olduğunu ifade etmişlerdir (5). Öğretim sürecinde öğrencilere kendi bilgilerini oluşturabilecekleri, sorgulayabilecekleri, araştırma yapabilecekleri ve çeşitli fikirler üreterek bu fikirlerini rahatça paylaşabilecekleri ortamlar oluşturmak önemlidir. Böylesi ortamlar hazırlamanın bir yöntemi de proje tabanlı öğretim ortamları sağlamaktır. Proje tabanlı öğretim ortamları ile öğrenciler ulusal ve uluslararası problemlere karşı daha duyarlı olacak, öğreneceği bilgileri uygulama ve kullanma imkanı bulacaklardır (6). Bu tarz çalışmalar öğrencilerin derslere ve araştırmalara olan ilgi ve motivasyonunu arttıracaktır (7).

Proje tabanlı öğretimin ana felsefesi yapılandırmacı yaklaşımı temel alır. Öğrenenin kendi bilgisini oluşturması öğrenmenin anlamlı ve etkili olmasını sağlamaktadır $(8,9)$. Bu öğretim yöntemi; konu seçimi, kaynak tarama, zaman takvimi ve maliyet hesabının yapılması, konu ile ilgili bilgilerin toplanma yöntemlerinin belirlenmesi, elde edilen bulguların derlenmesi ve raporlama aşamalarından oluşur (10). Yaparak ve yaşayarak öğrenmeyi sağlayan proje tabanlı öğretim, eğitmen bazlı sınıf içi uygulamalar yerine daha uzun süreçli, birçok disiplinler arası yaklaşımı kapsayan, küçük gruplar ile problem çözümünü amaçlayan, öğrenenlerin ilgisini ve istekliliğini arttıran, öğrenmeyi daha anlamlı bir duruma getiren, öz değerlendirmeyi ve kişilerarası iletişimi geliştiren bir yöntemdir (7,11-17). Proje tabanlı öğretim ortamlarında öğrenenin ne öğreneceği kadar nasıl ve niçin öğreneceği ön plandadır (18). Böylesi bir anlayış, öğrenenlerin bilgiyi ve bilgi edinme sürecini yapılandırarak keşfetmelerini sağlar (19). Öğrenenin, öğrenme sürecinde önemli bir sorumluluk alması gerektiğini temel alan bu yaklaşım, okuldaki öğrenmelerin öğrenen merkezli olmasını sağlar (20). Öğretmenin rolü ise süreci düzenleme, yönlendirme ve rehberlik etmedir (21). Kişilerin kendi bilgilerini oluşturması, sorgulaması, yaratması, problem çözmesi, derinlemesine anlaması yapılandırmacı öğrenmenin bir sonucu şeklinde açıklanır (22). Öğrenenler çoğunlukla gruplar halinde çalışır, temel nokta öğrenme ortamını öğrencilerin yeni bilgi ve becerileri etkili bir şekilde inşa 
edebilecekleri şekilde yapılandırmaktır (23). Bu tür ortamlar öğrenenin çalışma isteğini pekiştirecektir. $\mathrm{Bu}$ ortamlar; öğrenenlerin okul ve derslere daha iyi uyum sağlamalarına, derslerinden daha yüksek başarı elde etmelerine, öğrenmeye yönelik olumlu tutumlar kazanmalarına, daha fazla çaba harcamalarına, kendilerine güvenmelerine, zor araştırmaları sonuçlandırmak için ısrarcı davranmalarına, bilgiyi hatırlamalarına ve bilginin gerekliliğini anlamalarına neden olacaktır $(24,25)$.

Günümüzde bilgiyi üreten, derleyen, sorgulayan, kanıt temelli çalışan hemşirelere ihtiyaç vardır. Hemşirelik biliminde kanıta dayalı uygulamaların kullanılması ve bilim teknoloji alanındaki gelişmeler hemşirelerin yeni öğrenme hedefleri ve yeni öğrenme stratejileri geliştirmelerini gerektirmektedir (26). Proje tabanlı öğretime ilişkin hemşirelik alanında yapılan çalışmalar incelendiğinde çalışmaların genellikle proje tabanlı eğitimin öğrencilerin sosyal becerilerine, öz etkililik-öz yeterliliklerine ve yaşam boyu öğrenme eğilimleri üzerine etkisine yönelik olduğu görülmüştür $(27,28)$. Bu çalışmada amaç öğrencilerin proje tabanlı öğretime dayalı olarak aldıkları dersin öğrencilerin öğrenme tutumlarına ve öğretme- öğrenme ortamı algılarına etkisini incelemektir. $\mathrm{Bu}$ çalışmalar sonucunda elde edilen veriler doğrultusunda öğretim ortamlarının düzenlenmesi, yeni öğretim yöntemlerinin aktif olarak kullanılması ve öğrencilerin kendilerini daha rahat ifade edeceği ortamlar yaratılması sağlanabilir.

\section{GEREÇ VE YÖNTEMLER}

\section{Araştırmanın amacı ve tipi}

$\mathrm{Bu}$ araştırmanın amacı proje tabanlı öğretimin öğrencilerin öğrenme tutumlarına ve öğretme-öğrenme ortamı algılarına etkisini belirlemektir. Araştırma tek grup ön test-son test yarı deneysel bir çalışmadır.

\section{Araştırmanın evren ve örneklemi}

Araştırmanın evrenini Türkiye'nin batısındaki bir üniversitenin hemşirelik fakültesinde 2019-2020 eğitim öğretim y1lında hemşirelikte öğretim dersi alan 260 öğrenci oluşturdu.

Araştırmada örneklem hacminin hesaplanması, Karaçallı ve Korur (2014) tarafindan proje tabanlı öğretim yönteminin öğrencilerin akademik başarı ve tutumlarını değerlendirdikleri bir çalışmaya dayalı olarak yapıldı (29). Bu araştırmaya dayalı yapılan analizde, G*Power 3.1.7 ile power: $0.80, \alpha=0.05$, örneklem; 220 ve t- testi kullanılarak gerçekleştirilen hesaplamada effect size: 0.246 bulundu. Bu araştırmanın örneklemine alınması gereken en az birey sayısı G*Power 3.1.9.2 ile effect size:0.30, $\alpha=0.05$, power: 0.80 ve t testi yapılacağ 1 varsayımı ile hesaplanmış ve 63 olarak bulundu. Araştırmaya, olası vaka kayıpları da düşünülerek, olasılıksız örnekleme yöntemi ile derse devam eden ve ön test son test uygulamalarının ikisine de katılması öngörülen toplam 260 kişinin alınması planlandı. Araştırma, araştırmaya katılmayı kabul eden ve proje tabanlı eğitimin tüm aşamalarına katılan 133 öğrenci ile tamamlandı.

\section{Veri toplama araçları}

Veriler öğrencileri tanıtıcı özellikleri içeren "Bilgi Formu”, “Öğrenmeye İlişkin Tutum Ölçeği”, "Öğretme-Öğrenme Ortamı Algısı Ölçeği” ile toplanmıştır. 
Bilgi Formu: $\mathrm{Bu}$ form öğrencilerin yaş, cinsiyet, medeni durum, yaşadı̆̆ mezun olduğu okul, mesleği isteyerek seçme, hemşirelik eğitiminden memnuniyet bilgilerini içeren sorulardan oluşmaktadır.

Öğrenmeye İlişkin Tutum Ölçeği: Kara (2010) tarafından geliştirilip geçerlilik ve güvenirlilik çalışmaları aynı kişi tarafından yapılan ölçek 40 madden oluşmaktadır ve maddeler 5'li likert derecelendirme (Hiç Katılmıyorum, Kısmen Katılmıyorum, Kararsızım, Çoğunlukla Katılıyorum, Tamamen Katılıyorum) ile hazırlanmıştır. Ölçekte belirlenen olumsuz cümlelerin cevapları "Tamamen Katılıyorum:5 den " Hiç Katılmıyorum” 1 'e doğru puanlanmıştır. Ölçeğin Cronbach alpha iç tutarlılık katsayısı:. 73 olarak belirlenmiştir (4).

Öğretme-Öğrenme Ortamı Algısı Ölçeği: Ekinci (2008) tarafından geliştirilen ölçek, beşli likert tipi (1-Hiç yansıtmıyor-5 Tam yansıtıyor) bir ölçek olup (1) Öğretme-Öğrenme Etkinlikleri, (2) Değerlendirme ve (3) İş yükü boyutlarından oluşmaktadır. Ölçekte birinci boyutta 17, ikinci boyutta 9 ve üçüncü boyutta 5 olmak üzere toplam 31 madde yer almaktadır. Ölçeğin güvenirlik düzeyine ilişkin hesaplanan Cronbach Alpha $(\alpha)$ değerleri birinci boyut için, 89, ikinci boyut için 84 , üçüncü boyut için 65 ve bütünü için 86 'dır. Ölçeğin minimum, orta ve maksimum puanları öğretim etkinliklerinde; alabilecekleri en yüksek puan 85 , orta puan 51, en düşük puan 17dir. Ölçeğin değerlendirme boyutundan alınabilecek en yüksek puan 45, orta puan 27, en düşük puan 9 dur. Ölçekte bazı maddeler ters puanlanmıştır. Ölçeğin iş yükü boyutundan alınabilecek en yüksek puan 25, orta puan 15, en düşük puan 5'dr. Ölçeğin genel öğrenme-öğretme ortamı algısı için en yüksek puan 155, orta puan 93, en düşük puan 31 dir (30). Puanların alınabilecek en üst puana yakınlık derecesi öğretme-öğrenme ortamının, derinlemesine öğrenmeye yönlendirici olma derecesini ortaya koyarken, uzaklaşma derecesi ortamın derinlemesine öğrenmeye yönlendirici olmaktan uzaklaşma derecesini ortaya koyduğu şeklinde değerlendirilmektedir.

\section{Araştırmanın uygulanması}

Araştırma verileri proje tabanlı öğretim yöntemine göre yürütülen "Hemşirelikte Öğretim” dersinin uygulaması sürecinde toplandı. Veriler araştırmacı tarafindan, çalışmanın amacı ve önemi, veri toplama formları öğrencilere açıklandıktan sonra gönüllü öğrencilere sınıfta veri toplama formları dağıtılarak topland.

Bu dersin uygulaması sürecinde tüm öğrenciler 10-12 kişiden oluşan çalışma gruplarına ayrıld1. İlk aşamada öğrencilerden bir proje konusu belirlemeleri istendi. Her bir grup kapsamlı literatür taraması yaparak sınıf önünde bu projenin kabulü için savunma yaptı. Daha sonra proje konusuna ilişkin dersin teorik bölümünde öğretilen bir eğitim planını adım adım uygulamaları istendi. $\mathrm{Bu}$ doğrultuda proje konusunda belirtilen eğitimin amaç ve hedeflerini belirleyerek literatür taraması eşliğinde içerik planı hazırlama, ve bir eğitim planı oluşturma süreçleri tamamlandı. Öğrenciler bu eğitim planını oluşturma sırasında kapsamlı literatür taraması yaptı, gerektiğinde uzman kişi ve kurumlarla görüştü. Bu aşamada öğrencinin bilgiye ulaşması, literatüre hakim olması ve eğitim plan ve uygulamasını etkileyen faktörleri de dikkate alarak bir eğitim planı oluşturması hedeflendi. Öğrenciler literatür doğrultusunda ve tüm literatürü harmanlayarak verilen yazım kuralları doğrultusunda proje konusuna ilişkin eğitim içeriğini yazılı hale getirdi. Eğitim içeriği, eğitim amaç ve hedefleri doğrultusunda öğrencilerden uygun öğretim yöntem ve teknikleri ile öğretim araç gereçlerine karar vermeleri ve hazırlamaları 
istendi. Öğrenciler proje çalışmalarını eğitim planı doğrultusunda, belirledikleri öğretim yöntem ve teknikleri ile öğretim araç-gereçlerini etkili sunum tekniklerine uygun olarak tüm dersi alan öğrenciler ve dersin öğretim elemanları önünde sundu. Sunum sonrasında hem kendileri proje çalışmasına ilişkin geri bildirim verdi, hem de sınıf ve öğretim elemanları tarafından geri bildirim aldılar. Tüm bu aşamalarda öğretim elemanları gerekli teorik bilgiyi vermenin yanı sıra öğrencilere rehberlik yaparak süreci doğru yönetmelerine yardımcı oldu. Proje uygulaması sonunda öğrencilere öğrenmeye ilişkin tutum ölçeği ve öğretme-öğrenme ortamı algısı ölçeği uygulandı.

\section{Araştırmanın etik boyutu}

Araştırmanın yürütülmesi için, Adnan Menderes Üniversitesi Hemşirelik Fakültesi Girişimsel Olmayan Klinik Araştırmalar Etik Kurulundan (14.10.2019 tarihli, III Nolu karar ve 50107718-050.99 sayılı) onay, çalışmanın yürütüldüğü ilgili kurumdan yazılı izin, öğrencilerden ise yazılı onam alındı.

\section{Araştırmanın sınırlılıkları}

Araştırma, sadece bir üniversitede eğitim gören hemşirelik öğrencilerinde yürütülmüştür. $\mathrm{Bu}$ nedenle Türkiye'deki tüm hemşirelik öğrencilerine genellenemez. Çalışmada veri toplamak amacıyla bilgi formu ve iki ölçüm aracının kullanılması, öğrencilerin yanıtlarını bu formlarda yer alan ifadeler ile sınırlamıştır. Çalışmanın dersin işlenişi gereği tek grup ön test-son test yarı deneysel bir çalışma olarak yürütülmesi bir kontrol grubu bulunmaması, son test ölçümlerinin final sınavlarına çok yakın bir tarihe rastliyor olması çalışmanın diğer sınırlılıklarıdır.

\section{Verilerin değerlendirilmesi}

Elde edilen veriler SPSS 18.0 (Statistical Package for Social Sciences) programinda analiz edildi. Verilerin değerlendirilmesinde frekans, yüzde, aritmetik ortalama hesaplandı. Ölçek puanlarının normal dağılma uygunluğunu belirlemek için normallik testi yapıldı. Ölçek puanları normal dağılım gösterdiği (Kolmogorov-Smirnov p >0.05) belirlendi. Verilerin değerlendirilmesinde t-testi (Paried Samples t-test) analizi kullanıldı. Analizlerde $\mathrm{p}<0.05$ istatistiksel olarak anlamlı kabul edildi.

\section{BULGULAR}

Araştırmaya katılan öğrencilerin yaş ortalaması 21.71 \pm 1.40 olup, \%74.4'ü kı, \%97.7'si bekard1. Araştırmada öğrencilerin \%94.7'sinin düz lise mezunu olduğu, \% 43.6'sının öğrenci yurdunda kaldığı, \%66.9'unun mesleği isteyerek tercih ettiği ve \%49.6'sının eğitimden kısmen memnun olduğu belirlendi.

Öğrencilerin öğrenmeye ilişkin tutum ölçeği alt faktör puan ortalamaları incelendiğinde öğrencilerin tüm alt faktör puan ortalamalarının proje tabanlı öğretim öncesi ve sonrası oldukça yüksek olduğu öğrenmenin doğasına ilişkin puan ortalamalarının proje tabanlı öğretim sonrası anlamlı düzeyde azaldığı $(\mathrm{p}<0.05)$, diğer alt faktörler açısından anlamlı bir fark olmadığ ( $>0.05)$ saptand 1 (Tablo 1$)$. 
Tablo 1. Öğrencilerin Proje Tabanlı Öğretim Öncesi ve Sonrası Öğrenme Tutumları Ölçeği Puan Ortalamalarının Karşılaştırılması

\begin{tabular}{|c|c|c|c|c|c|c|}
\hline \multirow{2}{*}{$\begin{array}{l}\text { Öğrenmeye İlişkin Tutum Ölçeği } \\
\text { Alt Faktörleri }\end{array}$} & \multirow{2}{*}{$\begin{array}{l}\text { Ölçek Min- } \\
\text { Max. Puan } \\
\text { Aralığı }\end{array}$} & \multicolumn{2}{|c|}{ Ön-Test } & \multicolumn{2}{|c|}{ Son Test } & \multirow{2}{*}{$\begin{array}{c}\text { İstatistiksel } \\
\text { Analiz } \\
\text { t/p }\end{array}$} \\
\hline & & $\mathbf{X}$ & SS & $\mathbf{X}$ & SS & \\
\hline Öğrenmenin Doğası & $7-35$ & 30.87 & 3.34 & 29.13 & 4.40 & $3.96 / 0.00$ \\
\hline Öğrenmeye İlişkin Beklentiler & $9-45$ & 40.20 & 4.30 & 39.70 & 5.43 & $0.99 / 0.32$ \\
\hline Öğrenmeye Açıklık & $11-55$ & 45.52 & 6.09 & 45.00 & 7.44 & $0.79 / 0.42$ \\
\hline Öğrenmeye İlişkin Kaygılar & $13-65$ & 38.09 & 6.22 & 37.33 & 6.45 & $1.33 / 0.18$ \\
\hline
\end{tabular}

Öğrencilerin öğrenme-öğretme ortamı algısı ölçeği alt faktör puan ortalamaları incelendiğinde öğrencilerin proje tabanlı öğretim sonrası öğretme-öğrenme etkinliklerine ilişkin algılarının anlamlı düzeyde arttığı $(\mathrm{p}<0.05)$, değerlendirme ve iş yükü algılarının ise anlamlı düzeyde azaldığı $(\mathrm{p}<0.05)$ belirlendi (Tablo 2).

Tablo 2. Öğrencilerin Proje Tabanlı Öğretim Öncesi ve Sonrası Öğretme-Öğrenme Ortamı Algısı Ölçeği Puan Ortalamalarının Karşılaştırılması

\begin{tabular}{|c|c|c|c|c|c|c|}
\hline \multirow{2}{*}{$\begin{array}{l}\text { Öğgretme-Öğrenme Ortamı Algısı } \\
\text { Ölçeği Alt Faktörleri }\end{array}$} & \multirow{2}{*}{$\begin{array}{l}\text { Ölçek Min- } \\
\text { Max. Puan } \\
\text { Aralığı }\end{array}$} & \multicolumn{2}{|c|}{ Ön-Test } & \multicolumn{2}{|c|}{ Son Test } & \multirow{2}{*}{$\begin{array}{l}\text { İstatistiksel } \\
\text { Analiz }\end{array}$} \\
\hline & & $\mathbf{X}$ & SS & $\mathbf{X}$ & SS & \\
\hline Öğretme-Öğrenme Etkinlikleri & $\begin{array}{c}17-85 \\
\text { Orta puan: } \\
51\end{array}$ & 50.48 & 11.13 & 57.09 & 11.93 & $-6.24 / 0.00$ \\
\hline Değerlendirme & $\begin{array}{c}9-45 \\
\text { Orta puan:27 }\end{array}$ & 23.87 & 6.45 & 19.17 & 3.67 & $6.93 / 0.00$ \\
\hline İş Yükü & $\begin{array}{c}5-25 \\
\text { Orta puan: } 15\end{array}$ & 13.93 & 3.53 & 11.12 & 2.67 & $7.22 / 0.00$ \\
\hline Öğretme-Öğrenme Ortamı Algısı & $\begin{array}{c}31-155 \\
\text { Orta puan:93 }\end{array}$ & 88.30 & 16.41 & 99.11 & 16.43 & $-7.35 / 0.00$ \\
\hline
\end{tabular}

\section{TARTIŞMA}

Proje tabanlı öğretimin öğrencilerin öğretme- öğrenme tutumlarına ve öğretim ortamı algılarına etkisini incelemek amacıyla yapılan bu çalışmada öğrencilerin öğrenmeye ilişkin tutumlarının oldukça yüksek olduğu saptanmıştır. Denat (2019) tarafindan hemşirelik öğrencilerinin öğrenme tutumlarını belirlemeye ilişkin yapılan çalışma sonuçları bu çalışmanın sonuçları ile benzer nitelikte olup hemşirelik öğrencilerinin öğrenme tutumları oldukça yüksektir (31).

Çalışmada proje tabanlı öğretimin genel olarak öğrenmeye ilişkin tutumlarda anlamlı bir fark yaratmadığı sadece öğrenmenin doğasına ilişkin tutumları anlamlı düzeyde değiştirdiği saptanmıştır. Bu çalışmada proje tabanlı öğretim sadece bir dönemlik bir zamanda ve sadece bir derste kullanılmıştır. Uzun sürede değişmesi beklenen öğrenme tutumlarında herhangi bir değişim olmamasının bu durumdan kaynaklandığı düşünülmektedir. Nitekim Kiraz ve ark (2019) tarafından beceri eğitiminde simülasyon kullanımının öğrencilerin öğrenme tutumlarına etkisine yönelik yapılan çalışmada da benzer sonuçlar elde edilmiş, öğrenme tutumlarında kısıtlı bir süre ve beceride yapılan eğitimin öğrenme tutumlarını değiştirmediği saptanmıştır (32). Çalışmada proje tabanlı öğretimin öğrenmenin doğasına ilişkin tutumları anlamlı düzeyde değiştirdiği, öğrenmenin doğasına ilişkin tutum puanlarının düştüğü saptanmıştır. Ölçeğin öğrenmenin doğasına ilişkin tutumlarını belirleyen maddeleri incelendiğinde maddelerde zeki olanların daha iyi öğreneceği, öğrenmede zekânın önemli olduğu ve öğrenmenin belli bir yaşa 
kadar sınırlı olmadığı, her insanın öğrenme kapasitesinin farklı olduğu ve zeki insanların daha iyi öğreneceği gibi madde ifadeleri yer almakta olup öğrenmenin doğasına ilişkin genel öğrenilmişliklere vurgu yapılmaktadır. Proje tabanlı öğretim sonrası öğrencilerin öğrenmenin doğasına ilişkin tutumlarındaki değişim bu öğretim yönteminin doğası gereği beklenen bir durumdur. Çünkü proje tabanlı öğretim klasik öğretimden farklı olarak öğrenci merkezlidir ve yaparak yaşayarak öğrenme, disiplinler arası yaklaşım, problem çözme odaklıdır. Ayrıca öğrencilerin ilgilerini, isteklerini arttıran, öğrenmeyi daha anlamlı kılan, öz değerlendirmeyi, karar vermeyi geliştiren ve kişilerarası iletişimi geliştiren bir öğretim yöntemidir. Bu öğretimde öğrencinin bilgisini kendi kendine oluşturması, öğrenmede sorumluluk alması, öğrenmenin anlamlı ve etkili olması amaçlanır (7-9,11-17,20). Çalışmada istatistiksel olarak anlamlı bir fark olmamasına rağmen proje tabanlı öğretim sonrası öğrenmeye ilişkin kaygı puan ortalamalarında düşme gözlenmektedir. Kaygının öğrenme sürecinde önemli bir faktör olduğu, artan kaygının öğrenme sürecini negatif etkilediği $(33,34)$ göz önünde bulundurulursa proje tabanlı öğretiminde kaygıyı azaltıcı yönde etkileyebileceği düşünülmektedir.

Çalışmada proje tabanlı öğretimin öğrencilerin öğretim ortamı algılarına etkisi incelendiğinde proje tabanlı öğretim öncesi öğrencilerin öğretme-öğrenme ortamını derinlemesine öğrenmeye yönlendirici olarak algılama düzeylerinin orta düzeyin altında olduğu proje tabanlı öğretim sonrası bu algının orta düzeyin üstüne çıktığı belirlenmiştir. Ekinci (2008) tarafından üniversite öğrencileri ile yapılan çalışmada öğrencilerin öğretme-öğrenme ortamını derinlemesine öğrenmeye yönlendirici olarak algılama düzeylerinin orta düzeyin altında olduğu saptanmıştır. Bu çalışma sonuçlarına göre hemşirelik öğrencilerinin öğrenme-öğretme ortamı algılarının diğer üniversite öğrencilerinin algıları ile benzer nitelikte olduğu söylenebilir. Öğrencilerin genel öğretme-öğrenme ortamı algısındaki artış öğrencilerin öğretme-öğrenme ortamını derinlemesine öğrenmeye yönlendirici olma derecesini ortaya koymaktadır $(30,35)$. $\mathrm{Bu}$ çalışmada proje tabanlı öğretimin genel öğretme-öğrenme ortamının ve öğrenme- öğretme etkinliklerinin derinlemesine öğrenmeye yönlendirici olarak algılamalarını anlamlı düzeyde arttığ1 saptanmıştır. Öğrencilerin öğretme-öğrenme ortamını derinlemesine öğrenmeye yönlendirici olarak algılama düzeyleri arttıkça, derinlemesine ve stratejik bir öğrenme tercihi eğilimleri de artmaktadır. Öğrencilerin öğretme-öğrenme ortamına yönelik olumlu algılar1 azaldıkça, yüzeysel öğrenmeyi seçmeler artmaktadır. (30,35). Erdoğan (2012) tarafindan proje tabanlı öğrenmenin öğrenme ortamı ile ilgili algılara ve başarıya etkisini incelemek amacıyla yapılan çalışmada proje tabanlı öğrenmenin öğrencileri araştırmaya yönlendirdiği, konuyu öğrenmelerini kolaylaştırdığ 1 , dersteki konular ve günlük yaşamdaki problemler arasında neden sonuç ilişkisi kurulmasına, kendi bilgisini oluşturmasına, öğrenmenin daha anlamlı ve etkili olmasına katkıda bulunduğu belirlenmiştir (7).

Ramsden (2000) derinlemesine öğrenmeyi seçen öğrencilerin anlama amac1 taşıdıklarını, öğrenmenin nasıl gerçekleştiği ile ilgilendiklerini, konuya ilişkin kuramsal bilgilerle günlük yaşantıları arasında bağ kurduklarını, kullandıkları içeriği birbiriyle uyumlu bir bütün haline dönüştürerek yapılandırdıklarını ifade etmektedir (36). Öğrenciler derinlemesine öğrenme yaklaşımını kullandıklarında önemseme, ilgi duyma, öğrenmeden zevk alma gibi olumlu tutumlara da sahip olabilmektedirler (37). Nitekim çalışma sonucuna göre proje tabanlı öğretimin öğrenme konusunu ele alırken, anlam arama ve anlam oluşturmaya ilişkin derinlemesine bir surece diğer bir ifade ile derinlemesine öğrenmeye yönlendirdiği söylenebilir. 
Çalışma sonucunda proje tabanlı öğretim sonrası değerlendirme ve iş yükü puan ortalamalarının anlamlı derecede düştügü saptanmıştır. Bu sonuç doğrultusunda proje tabanlı öğretimin değerlendirme odaklı bir öğrenme ortamından uzak ve daha az iş yükü algısı yarattığ 1 söylenebilir. Oysaki proje tabanlı öğretim öğrencinin kendi bilgisini kendisinin oluşturması, konu seçimi, kaynak tarama, elde edilen bulguların derlenmesi, raporlanması ve sunulması aşamalarından oluşmaktadır (10). Öğrencinin yaparak ve yaşayarak öğrenmesini destekleyen proje tabanlı öğretim yönteminde öğrenci oldukça aktiftir ve öğrenciye oldukça fazla iş yükü düşmektedir. Fakat çalışma sonuçlarımız proje tabanlı öğrenme sürecinin öğrencilerin iş yükü algısını değiştirdiği saptanmıştır. Nitekim Ekinci (2008) tarafından yapılan çalışmada öğrencilerin iş yükü algısının öğrenme yönelimini belirlemede etkili olduğu belirtilmiştir. Aynı çalışmada fazla iş yükü algısı ile yüzeyel öğrenme yaklaşımını tercihi arasında bir ilişki olduğu saptanmıştır (30). Bu çalışmada proje tabanlı öğrenmenin iş yükü algısını düşürdüğü saptanmıştır.

Çalışmada proje tabanlı öğretim sonrası değerlendirme alt boyut puan ortalamalarının anlamlı olarak düştüğü saptanmıştır. Bu sonuç değerlendirme boyutunun öğrencilerin öğrenme öğretme ortamı algısının derinlemesine öğrenmeden uzaklaştırdığııı göstermektedir. Ramsden (2000) yüzeyel öğrenme yaklaşımını seçen öğrencilerin sadece görevin gereklerini yerine getirme amacında olduklarını bununla birlikte değerlendirmeye ilişkin bilgileri ezberlediklerini, temel birtakım ilkeleri örneklerden ayırma sırasında başarısız olduklarını ve öğrenmeyi dışarıdan gelen zorlama olarak gördüklerini belirtmektedir (36). Bu çalışmada proje tabanlı öğrenme yöntemi süresince öğrenciler hem öğretim elemanları hem de çalışma grubundaki diğer arkadaşları tarafından değerlendirilmektedir. Sürecin farklı aşamalarında farklı değerlendirme yöntemleri söz konusudur. Öğrenciler bu yöntemden memnuniyetlerini bireysel olarak değerlendirseler de son test uygulamasının genel sınavlar öncesi bir zamana rastlamasının bu sonucu etkilediğini düşündürmektedir.

\section{SONUÇ VE ÖNERILER}

Bu çalışma sonucunda proje tabanlı öğretimin öğrencilerin öğrenmenin doğasına ilişkin tutumlarını değiştirdiği, öğrenme-öğrenme ortamı algılarını derinlemesine öğrenmeye yönlendirmesinin yanı sıra değerlendirme bazında derinlemesine öğrenmeden uzaklaştırdığ saptandı. Çalışma sonuçları göstermektedir ki hemşirelik eğitiminde proje tabanlı öğrenme daha fazla uygulanmalı hatta farklı derslerde ve eğitim seviyelerinde de uygulanarak uzun dönemdeki sonuçları da değerlendirilmelidir. Proje tabanlı öğretimin etkinliğini değerlendirmek adına kontrol gruplu çalışmaların planlanması, farklı öğretim yöntemlerinin uygulandığ 1 ders/kurumlarla karşılaştırılması önerilebilir.

\section{Araştırmanın Etik Yönü}

Araştırmanın yürütülmesi için, Adnan Menderes Üniversitesi Hemşirelik Fakültesi Girişimsel Olmayan Klinik Araştırmalar Etik Kurulundan (14.10.2019 tarihli, III Nolu karar ve 50107718-050.99 sayılı) onay, çalışmanın yürütüldüğü ilgili kurumdan yazılı izin, öğrencilerden ise yazılı onam alındı. 


\section{Çıkar Çatışması}

Yazarlar arasında çıkar çatışması yoktur.

\section{KAYNAKLAR}

1. Braten, I. \& Stromso, H. I. (2007). Epistemologicall beliefs, interest, and gender as predictors of internet based learning activities. Computer in Human Behavior, 22, $1027-$ 1042.

2. Duarte, A. M. (2007). Conceptions of learning and approaches to learning in Portuguese students. Higher Education, 54(6), 781-794.

3. Özden, M. (2009). An investigation of some factors affecting attitudes toward chemistry in university education. Essays in Education, Special Edition, 90-99.

4. Kara, A. (2010). Öğrenmeye ilişkin tutum ölçeğinin geliştirilmesi. Elektronik Sosyal Bilimler Dergisi, 9(32), 49-62.

5. Karagiannopoulou, E. \& Christtodoulides, P. (2005). The impact of greek university students' perceptions of their learning environment on approaches to studying and academic outcomes. International Journal of Educational Research, 43, 329-350.

6. Hele, L., Päivi Tynjälä, P. \& Olkinuora, E. (2006) Project-based learning in postsecondary education -theory, practice and rubber sling shots. Higher Education, 51(2), 287-314.

7. Erdoğan, İ. (2012). Proje tabanlı öğrenme yaklaşımının öğrenme ortamı ile ilgili algılara ve başarıya etkisi. Sakarya Üniversity Journal of Education, 2(3), 21-33.

8. Blumenfeld, P., Soloway, E., Marx, R., Krajcik, J., Guzdial, M., \& Palincsar, A. (1991). Motivating project-based learning: Sustaining the doing, supporting the learning. Educational Psychologist, 26(3 ve 4), 369-398.

9. Bransford, J. D., Brown, A. L., \& Cocking, R. R. (Ed.). (2000). How people learn: Brain, mind, experience, and school. Washington, DC: National Academy Press.

10. Memisoğlu, H. (2001). Sosyal Bilgiler Dersi Öğretiminde Proje Tabanlı Öğrenme Yaklaşımı. (Yayımlanmamış Doktora Tezi). Gazi Üniversitesi, Eğitim Bilimleri Enstitüsü, Ankara.

11. Akçin, E. (2006). Aktif öğretim yöntemi olarak proje tabanlı öğretim. Çağdaş Ĕ̆itim Dergisi, 328, 40-45.

12. Çıbık, A. S. (2009). Proje tabanlı öğrenme yaklaşımının öğrencilerin Fen Bilgisi dersine yönelik tutumlarına etkisi. İlköğretim Online, 8(1), 36-47.

13. Önen, F., Mertoğlu, H., Saka, M. \& Gürdal, A. (2010). Hizmetiçi eğitimin öğretmenlerin proje ve proje tabanlı öğrenmeye ilişkin bilgilerine ve proje yapma yeterliklerine etkisi: Öpyep örneği. Ahi Evran Üniversitesi Ĕ̈itim Fakültesi Dergisi, 11(1), 137-158.

14. Zorbaz, K. \& Çeçen- Aktif, M. (2009). Proje tabanlı öğretim ve Türkçe öğretiminde kullanımı. Ankara Üniversitesi Ĕ̈itim Bilimleri Fakültesi Dergisi, 42(1), 87-104.

15. Ay, Ş. (2010). Öğretmen adaylarının çeşitli değişkenler açısından proje tabanlı öğrenmeye ilişkin görüşleri. Çăgdaş Ĕ̆itim Dergisi, 35(375), 12-19.

16. Gürol, M. (2004). Öğretimde planlama uygulama değerlendirme. Gürol, M. (Ed.). Öğretim Sürecinde İletişim, Model ve Uygulamalar. Elazı̆̆: Üniversite Kitabevi.

17. Özdener, N. \& Özçoban, T. (2004). Bilgisayar eğitiminde çoklu zekâ kuramına göre proje tabanlı öğrenme modelinin öğrenci başarısı üzerine etkisi. Kuram ve Uygulamada Ĕgitim Bilimleri, 4(1), 147-170.

18. Erdem, E. \& Demirel, Ö. (2002). Program geliştirmede yapılandırmacılık yaklaşımı. Hacettepe Üniversitesi Eğitim Fakültesi Dergisi, 23, 81-87. 
19. Fer, S. \& Cirık, İ. (2006). Öğretmenlerde ve öğrencilerde, yapılandırmacı öğrenme ortamı ölçeğinin geçerlik ve güvenirlik çalışması nedir. Yeditepe Üniversitesi Eğitim Fakültesi Dergisi, 2(1), 1-26.

20. Gömleksiz, M. N. \& Elaldı, Ş. (2011). Yapılandırmacı yaklaşım bağlamında yabancı dil öğretimi. Turkish Studies, 6(2), 443-454.

21. Kurt, M. (2016). Yapılandırmacılık kuramı. G.Ekici (Edt.). Öğrenme-Öğretme Kuramlarl ve Uygulamadaki Yansimalarl. Ankara; Pegem Yayıncılık.

22. Yurdakul, B. (2008). Yapılandırmacı öğrenme yaklaşımının sosyal-bilişsel bağlamda bilgiyi oluşturmaya katkısı. Balıkesir Üniversitesi Sosyal Bilimler Enstitüsü Dergisi, 11(20), 39-67.

23. Schunk, D. H. (2009). Learning theories: an educational perspective (5th ed.). Upper Saddle River, 2009, New Jersey: Pearson Education, Inc.

24. Brewster, C. \& Fager J. (2000). Increasing student engagement and motivation: from time-on-task to homework. Portland, Ore.: Northwest Regional Educational Laboratory.

25. Savery, R. (2006). John overview of problem-based learning definitions and distinctions. The Interdisciplinary Journal of Problem-based Learning, 1(1), 9-20.

26. Karagözoğlu, Ş. (2005). Nursing as a scientific discipline. CU Journal of School of Nursing, 9(1), 6-14.

27. Şenyuva, E., Kaya, H. \& Bodur, G. (2015). Proje Tabanlı Öğretim Yönteminin Hemşirelik Öğrencilerinin Sosyal Becerilerine Etkisi. Florence Nightingale Hemşirelik Dergisi, 23(2), 116-125.

28. Tuğrul, E. \& Denat, Y. (2019). Proje tabanlı öğretimin öğrencilerin yaşam boyu öğrenme eğilimleri ve öz etkililik- öz yeterlik algısına etkisi. Turkiye Klinikleri J Nurs Sci. 11(3), 273-80.

29. Karaçallı, S. \& Korur F. (2014). The Effects of project-based learning on students' academic achievement, attitude, and retention of knowledge: the subject of "electricity in our lives, The Effects of Project-Based Learning, 114(5), 224-235.

30. Ekinci, N. (2008). Üniversite öğrencilerinin öğrenme yaklaşımlarının belirlenmesi ve öğretme-öğrenme süreci değişkenleri ile ilişkileri. (Yayınlanmamış Doktora Tezi). Hacettepe Üniversitesi Sosyal Bilimler Enstitüsü, Ankara.

31. Denat, Y. (2019). Hemşirelik öğrencilerinin öğrenme tutumları ve etkileyen etmenler. Sakarya Üniversitesi Holistik Sağllk Dergisi, 2(2), 10-21.

32. Kiraz, E. D. E., Türk, G,. Denat, Y., Bulut, S., Şahbaz, M., Tuğrul, E. ve ark. (2019). Beceri eğitiminde simülasyon kullanımının öğrencilerin anksiyete, öğrenme tutumları ve beceri düzeylerine etkisi. Hemşirelik Bilimi Dergisi, 2(1), 17-22.

33. Dikmen, M., Tuncer, M, \& Şimşek, M. (2018). Öğrenme stilleri ile öğrenmeye yönelik tutum arasındaki ilişki. Uluslararası Sosyal Araştırmalar Dergisi, 11(57), 387-400.

34. Aydın, S. \& Zengin, B. (2008). Yabancı Dil Öğreniminde kaygı: bir literatür özeti. Journal of Language and Linguistic Studies, 4(1), 81-94.

35. Ekinci, N. (2009). Üniversite öğrencilerinin öğrenme yaklaşımları. Education and Science, 34(151), 74-88.

36. Ramsden, P. (2000). Learnig to teaching in higher education. London: Newyork Routhladge Falmer.

37. Biggs, J. (1999). Teaching for quality learning at university. London: Open University Press. 